\title{
Oily Skin
}

National Cancer Institute

\section{Source}

National Cancer Institute. Oily Skin. NCI Thesaurus. Code C74591.

The pores of the skin are generally large and visible with a coarse or thick texture. The skin has a tendency to look dull and greasy and feels oily to the touch. 